\title{
Profile of clinical features, congenital heart disease and other comorbidities in children with Down syndrome in a tertiary care centre in Nigeria
}

\author{
*Wilson E Sadoh ${ }^{1}$, Fidelis E Eki-udoko ${ }^{1}$, Isoken A Isah ${ }^{1}$
}

Sri Lanka Journal of Child Health, 2018; 47(1): 50-55

\begin{abstract}
Background: Down syndrome (DS) is a common chromosomal disorder associated with congenital heart disease (CHD) which could lead to severe morbidity or mortality.
\end{abstract}

Objective: To determine the frequency and spectrum of clinical features, CHD and other comorbidities in children with DS in a tertiary care centre in Nigeria.

Method: Consecutive children with clinical features of DS were recruited. The frequency of clinical features and co-morbidities were noted. All the children had echocardiographic evaluation to identify those with CHD.

Results: A total of 64 children was recruited of which $36(56 \%)$ were male. Fifty one $(80 \%)$ had CHD of which atrio-ventricular septal defect (AVSD) was the commonest, being found in 20 $(39 \%)$ children. Common clinical features present were oblique eyes in $64(100 \%)$, depressed nasal bridge in $60(94 \%)$ low set ears in $53(83 \%)$ and epicanthal folds in $50(78 \%)$.

Conclusions: Prevalence of CHD amongst DS children in this study was $80 \%$ with AVSD being the commonest. The most prevalent clinical features seen in these children were oblique eyes, epicanthal fold, depressed nasal bridge, low set ears, hypertelorism and hypotonia.

DOI: http://dx.doi.org/10.4038/sljch.v47i1.8430

(Keywords: Down syndrome, congenital heart disease, clinical features)

\section{Introduction}

Down syndrome (DS) is the commonest chromosomal disorder ${ }^{1}$. In a large Nigerian

${ }^{1}$ University of Benin Teaching Hospital, Nigeria
${ }^{*}$ Correspondence: ehidiamen.sadoh@uniben.edu
(Received on 09 May 2017: Accepted after
revision on 16 June 2017)
The authors declare that there are no conflicts of
interest
Personal funding was used for the project.
Open Access Article published under the Creative

Commons Attribution CC-BY CC hospital, the incidence was reported to be 1 in 87 live births ${ }^{2}$. The incidence is associated with advanced maternal age ${ }^{3}$. DS is a significant cause of mental retardation in children and is associated with other morbidities such as leukaemia, Hirschsprung disease and cardiovascular anomalies $^{1,4,5}$. The most severe comorbidities are the cardiovascular anomalies and when untreated, they are often the cause of death in affected children ${ }^{6}$.

A variety of congenital heart disease (CHD) has been described in patients with DS. Atrioventricular canal defect (AVSD) has been reported to be the commonest CHD seen in children with $\mathrm{DS}^{1,7}$ while others have reported a preponderance of ventricular septal defect ${ }^{8}$. Otaigbe et $\mathrm{al}^{9}$ in Port Harcourt, Nigeria evaluated 31 children with DS, all of whom had CHD which included a fairly wide spectrum of both acyanotic and cyanotic CHD. The most common CHD was patent ductus arteriosus (PDA), contrary to the report of the study done by Onalo and co-worker ${ }^{10}$ in Abuja Nigeria where AVSD was the predominant CHD found amongst 20 children with DS studied. However, the sample sizes of the earlier Nigerian studies were rather small ${ }^{7,9,10}$.

There are typical dysmorphic features seen in DS patients that aid its clinical diagnosis ${ }^{1}$. The prevalence of these features varies from setting to setting as reported by various workers ${ }^{1,11,12}$. The differences may be due to the genetic variability. DS has high genotype variability and three types have been described viz. non-disjunction, unbalanced translocation and mosaicism ${ }^{1}$.

\section{Objectives}

The present study was conducted to determine the frequency and spectrum of clinical features, CHD and other comorbidities in children with DS seen at the University of Benin Teaching Hospital, Benin City, Nigeria, a tertiary care centre.

\section{Method}

All children clinically diagnosed to have DS who presented in the children's emergency room, paediatric wards and consultant out-patient clinics were referred to the echocardiographic laboratory of the University of Benin Teaching Hospital (UBTH), Benin City, Nigeria. It is the hospital policy to refer all suspected cases of DS for 
cardiologic evaluation. The study was carried out between July 2012 and December 2013. Ethical approval for the study was obtained from the research and ethics committee of the UBTH.

Using a pre-tested proforma, socio-demographic parameters of the children and parents and the clinical features of the children were obtained including age, gender, socioeconomic class (SEC), maternal and paternal ages. Each child then had a thorough clinical examination. Using a checklist, the clinical features associated with DS were noted. Other clinical signs of cardiovascular origin such as cyanosis, respiratory distress, chest wall abnormalities and cardiomegaly (displaced apex beat) were looked out for and documented. The presence of the co-morbidities of pneumonia, congestive cardiac failure (CCF) and pneumonia complicated with $\mathrm{CCF}$, for which the patients were referred for cardiologic evaluation, were also noted. The diagnosis of pneumonia was based on clinical findings and typical pulmonary infiltrates seen on chest radiograph. The diagnosis of heart failure was based on the clinical diagnostic tool by Omokhodion ${ }^{13}$. The SEC was determined using the methods described by Olusanya et $\mathrm{al}^{14}$. The patients' weights were measured using a bassinet weighing scale for infants and an appropriate weighing scale for older children, using standard methods. The $\mathrm{Z}$ scores of the weight for age were computed using the WHO growth charts for children $^{15}$

All the children with a clinical diagnosis of DS underwent transthoracic echocardiographic evaluation using 2D, $\mathrm{M}$ mode and Doppler interrogation using an Aloka Prosound SSD4000SV (Aloka, Meerbusch, Germany) machine. The analysis of the reports was done according to the recommendations of the American Society of echocardiography ${ }^{16}$. The presence and types of CHD on echocardiography were documented.

\section{Statistical analysis}

The data was entered into SPSS version 16 (Chicago IL) spread sheet and analysis done with the same tool. Simple proportions were expressed in percentages. Differences in proportions were tested with $\mathrm{X}^{2}$ test. Level of significance was set at $p<0.05$ level.

\section{Results}

Of the 64 children with DS, 36 (56.2\%) were male. The median age was 6 months with a range of 2 days to 15 years. The socio-demographic characteristics and parental age groups of the study population are shown in table I.

Table 1: Socio-demographic characteristics and parental age groups of the study population

\begin{tabular}{|c|c|c|c|c|}
\hline Characteristic & Males & Females & Total (\%) & P value \\
\hline $\begin{array}{l}\text { Age group } \\
<6 \text { months } \\
\geq 6 \text { month }-<12 \text { months } \\
\geq 12 \text { months }\end{array}$ & $\begin{array}{l}16 \\
08 \\
12\end{array}$ & $\begin{array}{l}09 \\
08 \\
11\end{array}$ & $\begin{array}{l}25(39.1) \\
16(25.0) \\
23(35.9)\end{array}$ & 0.60 \\
\hline $\begin{array}{l}\text { Nutritional status } \\
\text { Underweight } \\
\text { Normal weight } \\
\text { Overweight }\end{array}$ & $\begin{array}{l}20 \\
12 \\
01\end{array}$ & $\begin{array}{l}20 \\
09 \\
02\end{array}$ & $\begin{array}{l}40(62.5) \\
21(32.8) \\
03(04.7)\end{array}$ & 0.81 \\
\hline $\begin{array}{l}\text { Socioeconomic class } \\
\text { High } \\
\text { Middle } \\
\text { Middle }\end{array}$ & $\begin{array}{l}12 \\
16 \\
09\end{array}$ & $\begin{array}{l}11 \\
12 \\
04\end{array}$ & $\begin{array}{l}23(35.9) \\
28(43.8) \\
13(20.3)\end{array}$ & 0.44 \\
\hline $\begin{array}{l}\text { Maternal age } \\
<35 \text { years } \\
\geq 35 \text { years } \\
\end{array}$ & $\begin{array}{l}17 \\
19\end{array}$ & $\begin{array}{l}10 \\
18 \\
\end{array}$ & $\begin{array}{l}48(42.2) \\
16(57.8) \\
\end{array}$ & 0.45 \\
\hline $\begin{array}{l}\text { Paternal age } \\
<50 \text { years } \\
\geq 50 \text { years }\end{array}$ & $\begin{array}{l}30 \\
06\end{array}$ & $\begin{array}{l}24 \\
04\end{array}$ & $\begin{array}{l}54(84.4) \\
10(15.6)\end{array}$ & 1.00 \\
\hline
\end{tabular}

The frequency distribution of DS dysmorphic features in the study population is shown in table 2 . Brushfield spots were not seen in a single case in this study. Of the 64 children with clinical features of DS, $51(79.7 \%)$ children had CHD. Of the 51 cases 49 (96.1\%) were acyanotic CHD while two (3.9\%) were cyanotic CHD. Forty one $(80.4 \%)$ had isolated cardiac defects while $10(19.6 \%)$ had multiple cardiac defects. Three patients had surgery, two with complete atrio-ventricular septal defect (AVSD) and one with ventricular septal defect (VSD).

The distribution of the types of cardiac anomalies by gender is shown in table 3 . 
Table 2: The frequency of Down syndrome clinical features seen in the study population

\begin{tabular}{|l|c|c|c|}
\hline \multicolumn{1}{|c|}{ Clinical feature } & Males & Females & Total (\%) \\
\hline Oblique eyes & 36 & 28 & $64(100)$ \\
\hline Depressed nasal bridge & 36 & 24 & $60(93.8)$ \\
\hline Low set ears & 29 & 24 & $53(82.8)$ \\
\hline Epicanthal folds & 22 & 28 & $50(78.1)$ \\
\hline Hypertelorism & 28 & 19 & $47(73.4)$ \\
\hline Hypotonia & 23 & 23 & $46(71.9)$ \\
\hline Microglossia & 14 & 18 & $32(50.0)$ \\
\hline Short hands & 12 & 14 & $26(40.6)$ \\
\hline Brachycephaly & 12 & 14 & $26(40.6)$ \\
\hline Short neck & 12 & 14 & $26(40.6)$ \\
\hline Umbilical hernia & 11 & 12 & $23(35.9)$ \\
\hline Oval palate & 10 & 10 & $15(23.4)$ \\
\hline Single Simian crease & 06 & 09 & $14(21.9)$ \\
\hline Hyperextension of limbs & 07 & 07 & $05(07.8)$ \\
\hline Strabismus & 01 & 04 & $05(07.8)$ \\
\hline Ulnar loops & 01 & 04 & $01(01.6)$ \\
\hline Clinodactyly & 01 & 0 & \\
\hline
\end{tabular}

Table 3: Distribution of the types of CHD according to gender

\begin{tabular}{|l|c|c|c|}
\hline \multicolumn{1}{|c|}{ Cardiac anomaly } & Males & Females & Total (\%) \\
\hline Isolated AVSD & 11 & 09 & $20(39.2)$ \\
\hline Isolated ASD & 08 & 03 & $11(21.6)$ \\
\hline Isolated VSD & 06 & 03 & $09(17.6)$ \\
\hline VSD + ASD & 01 & 02 & $03(05.8)$ \\
\hline ASD + PDA & 01 & 02 & $03(05.8)$ \\
\hline AVSD + PDA & 0 & 01 & $01(02.0)$ \\
\hline VSD + PDA & 0 & 01 & $01(02.0)$ \\
\hline VSD + ASD + PDA & 01 & 0 & $01(02.0)$ \\
\hline Single ventricle & 0 & 01 & $01(02.0)$ \\
\hline PTA & 01 & 0 & $01(02.0)$ \\
\hline Total & 29 & 22 & $51(100.0)$ \\
\hline
\end{tabular}

$A V S D=$ Atrio-ventricular septal defect, $A S D=$ Atrial septal defect, $V S D=$ Ventricular septal defect, PDA $=$ Patent ductus arteriosus, PTA = Persistent truncus arteriosus,

The frequency distribution of some clinical findings and co-morbidities in the 64 children with clinical features of DS is shown in table 4.

Of the 14 children with co-morbidities, 06 (42.9\%) had bronchopneumonia, $05 \quad(35.7 \%)$ had bronchopneumonia and congestive cardiac failure (CCF) and 03 (21.4\%) had isolated CCF. All 09 $(14.1 \%)$ cases with cyanosis had cardiac anomalies. The anomalies included $06(66.7 \%)$ children with AVSD and one each (11.1\%) with persistent truncus arteriosus (PTA), VSD and single ventricle.

Table 4: Frequency distribution of clinical features and co-morbidities

\begin{tabular}{|l|c|c|}
\hline \multicolumn{1}{|c|}{ Features/ Co-morbidities } & Frequency & \% of total \\
\hline Murmur & 34 & 53.1 \\
\hline Respiratory distress & 28 & 43.8 \\
\hline Co-morbidities & 14 & 21.9 \\
\hline Displaced apex beat & 13 & 20.3 \\
\hline Bulging chest & 10 & 15.6 \\
\hline Cyanosis & 09 & 14.1 \\
\hline
\end{tabular}

A total of seven $(10.9 \%)$ deaths were recorded. Two of the deaths occurred at home after discharge from the hospital and five occurred in the hospital during the study period. The deaths were related to severe respiratory problems and the underlying congenital heart defects. Sixteen (25\%) of the 64 children with DS were lost to follow up while 38 $(59.4 \%)$ are being followed up in the clinic. 


\section{Discussion}

The prevalence of cardiac anomalies of $79.7 \%$ in this study is similar to the $77.1 \%$ recorded by Asani et $a l^{7}$ in Kano, Nigeria but lower than the $100 \%$ recoded by Otaigbe et al ${ }^{9}$ in Port Harcourt, Nigeria. The higher value recorded in the Port Harcourt study has been attributed to the fact that referral for echocardiography was based on the suspicion of possible cardiac defect while in the present study, all the children seen with DS were referred for echocardiographic evaluation irrespective of whether cardiac anomaly was suspected or not. The prevalence in our study is however higher than the 40 to $60 \%$ reported incidence studies globally ${ }^{17-19}$.

The majority of the children with DS in this study were underweight. This may be due to the fact that the prevalence of CHD was high in this study and the majority of the CHD were shunt lesions that could lead to recurrent pneumonia and heart failure. These co-morbidities would contribute to the underweight seen in these children. The finding of high prevalence of underweight children with DS is in tandem with the Brazilian study that showed that $78.2 \%$ of study subjects were underweight ${ }^{11}$.

The commonest CHD in this study was AVSD which is consistent with the $\mathrm{Kano}^{7}$ and Abuja ${ }^{10}$ studies in Nigeria and other previous works outside the country ${ }^{6,20}$. This is however at variance with the Port Harcourt ${ }^{9}$ study which recorded patent ductus arteriosus (PDA) as the commonest and a study in Riyadh, Saudi Arabia ${ }^{8}$ which recorded VSD as the commonest. It is not clear why there is a varied pattern in the distribution of CHD in different localities; it is possible that the genetic heterogeneity of the condition may be contributive.

The spectrum of CHD included complex congenital heart disease such as single ventricle and PTA. The presence of complex congenital heart defect was similarly reported in the Port Harcourt ${ }^{9}$ study where they found double outlet right ventricle. This finding of complex congenital heart diseases has been reported in other previous studies outside the country $^{8,21}$. Most (80.4\%) of the CHD recorded in this study were isolated lesions which is consistent with the Kano study and other studies outside the country ${ }^{7,8,22}$. In the Port Harcourt study ${ }^{9}$, however, the majority $(71 \%)$ of the patients with DS had multiple cardiac defects. It is not clear what is responsible for this finding. It is possible that it could be environmental; the higher prevalence of CHD in the oil rich Niger-Delta region of Nigeria has been alluded to in an earlier study ${ }^{23}$.

Two thirds of the patients with DS in this study were born to mothers younger than 35 years. This is consistent with previous studies that have shown a higher prevalence of DS born to younger mothers ${ }^{4,9}$. The occurrence of a growing number of children with DS born to younger mothers presents a strong reason for advocating DS screening for pregnant mothers as is done in some other countries $^{24,25}$. Two factors may militate against a successful screening programme in the country. It is expensive and may be beyond the reach of majority of Nigerians; however the cumulative cost of caring for a DS child certainly outweighs the cost of screening ${ }^{26}$. The other factor is managing the outcome of a positive screening result. Nigerian couples may be unlikely to accept termination of pregnancies because of their religious beliefs.

This study demonstrated that the clinical features present in patients with DS in the study locality in at least $70 \%$ of cases are oblique eyes, depressed nasal bridge, low set ears, epicanthal folds, hypertelorism and hypotonia. There is variation in the frequency of clinical features from locality to locality. For instance, single simian crease was present in $23.4 \%$ of the patients in this study; this is lower than the $39 \%$ recorded in the Port Harcourt study $^{9}$ and the $83.9 \%$ in the Brazilian study ${ }^{11}$. There were no Brushfield spots identified in this study, which is similar to a Korean study ${ }^{27}$, but at variance with a Jordanian $\operatorname{study}^{28}$ where $9 \%$ of children with DS had Brushfield spots. The difference in findings may be due to the known low frequency of Brushfield spots in DS individuals with dark coloured irides ${ }^{29}$.

Although in older infants and children, the features of DS are easily identifiable and thus a clinical diagnosis is made with a high level of certainty, in some others especially newborns, clinical diagnosis is less clear. The limitation of this study is the absence of cytogenetic studies to confirm DS in the suspected children. This was because the facility was not available.

\section{Conclusions}

- Prevalence of CHD amongst clinically diagnosed DS children in this study was $80 \%$ with AVSD being the commonest.

- The most prevalent clinical features seen in children with DS in this study were oblique eyes, epicanthal folds, depressed nasal bridge, low set ears, hypertelorism and hypotonia.

\section{References}

1. Summar K, Lee B. Down syndrome and other abnormalities of chromosomal number. In: Nelson Textbook of Pediatrics. $19^{\text {th }} \mathrm{ed}$, Kliegman RM, Stanton BF, St. Geme JW, Schor NF, Behrman 
RE. eds. Elsevier, Philadelphia, United States. 2011 pp $399-404$

2. Adeyokunnu AA. The incidence of Down syndrome in Nigeria. Journal of Medical Genetics 1982; 19:277-9.

https://doi.org/10.1136/jmg.19.4.277

PMid: 6214633 PMCid: PMC1048893

3. Owens JR, Harris F, Walker S, McAllister E, West L. The incidence of Down's syndrome over a 19 year period with special reference to maternal age. Journal of Medical Genetics 1983; 20:90-3.

https://doi.org/10.1136/jmg.20.2.90

PMid: 6221104 PMCid: PMC1049005

4. Torfs CP, Christianson RE. Anomalies in Down syndrome individuals in a large population-based registry. American Journal of Medical Genetics 1998; 77:431-8.

https://doi.org/10.1002/(SICI)10968628(1 9980605)77:5<431::AIDAJMG15>3.3.C $\mathrm{O} ; 2-\mathrm{Q}$

5. Asim A, Kumar A, Muthuswamy S, Jain S, Agarwal S. Down syndrome: an insight of the disease. Journal of Biomedical Science 2015; 22:41 https://doi.org/10.1186/s12929-015-0138y

PMid: 26062604 PMCid: PMC4464633

6. Spicer RL. Cardiovascular disease in Down syndrome. Pediatric Clinics of North America 1984; 31:1331-43. https://doi.org/10.1016/S00313955(16)34 725-3

7. Asani M, Aliyu I, Also U. pattern of congenital heart disease among children with Down syndrome seen in Aminu Kano Teaching hospital, Kano, Nigeria. Nigerian Journal of Basic and Clinical Sciences 2013; 10:57-9 https://doi.org/10.4103/0331-8540.122754

8. Al-Jarallah AS. Down syndrome and the pattern of congenital heart disease in a community with high parental consanguinity. Medical Science Monitor 2009; 15: CR409-12.

PMid: 19644417

9. Otaigbe BE, Tabansi PN, Agbedeyi GO. Pattern of congenital heart defects in children with Down syndrome at the University of Port Harcourt Teaching
Hospital, Port Harcourt. Nigerian Journal of Paediatrics 2012; 39(4):164-7. https://doi.org/10.4314/njp.v39i4.3

10. Onalo R, Babaniyi IB. Congenital cardiac defectds in children with Down syndrome as seen in the University of Abuja Teaching Hospital, Gwagwalada, Abuja. New Nigerian Journal of Clinical Research. 2014; 4:528-32

11. Bertelli ECP, Biselli JM, Bonfim D, Goloni-Bertollo EM. Clinical profile of children with Down syndrome treated in a genetics outpatient service in the Southeast of Brazil. Rev Assoc Med Bras 2009; 55:547-52

https://doi.org/10.1590/S01044230200900 0500017

12. Kava MP, Tullu MS, Muranjan MN, Girisha KM. Down syndrome: clinical profile from India. Archives of Medical Research 2004; 35:31-5. https://doi.org/10.1016/j.arcmed.2003.06. 005

PMid: 15036797

13. Omokhodion SI. Childhood heart failure. In: Omokhodion SI and Osinusi K. (Eds). Pediatric cardiology and respiratology. WACP update series (West African College of Physicians, Lagos, Nigeria) 1996. Pp 72-82

14. Olusanya O, Okpere E, Ezimokhai M. The importance of socio-economic class in voluntary infertility control in a developing country. West African Journal of Medicine $1985 ;$ 4:205-21.

15. WHO. Child growth standards. Found at www.who.int/entity/childgrowth/standards I (Assessed January 2011)

16. Amerian Society of Echocardiography. Recommendations for continous quality improvement in echocardiography. Journal of the American Society of Echocardiography 1995; 8:S1-28. PMid: 8588940

17. Ekure EN, Animashaun A, Bastos M, Ezeaka VC. Congenital heart disease associated with identified syndrome and other extra cardiac congenital malformations in children in Lagos. West African Journal of Medicine 2009; 28:337.

https://doi.org/10.4314/wajm.v28i1.48422 PMid: 19662743 
18. American Academy of Pediatrics Committee on Genetics. Health supervision for children with Down syndrome. Pediatrics 2001; 107(2):442-9. https://doi.org/10.1542/peds.107.2.442 PMid: 11158488

19. Nisli K, Oner N, Candan S, Kay-serili H, Tansel $\mathrm{T}$ et al. Congenital heart disease in children with Down syndrome: Turkish experience of 13 years. Acta Cardiol 2008; 63(2):585-9.

https://doi.org/10.2143/AC.63.5.2033225

PMid: 19014001

20. Freeman SB, Taft LF, Dookey KJ, Allran K, Sherman SL, Hassold TJ, et al. Population based study of congenital heart disease in down syndrome. American Journal of Medical Genetics 1998; 80(3):213-7.

https://doi.org/10.1002/(SICI)10968628(1 9981116)80:3<213::AIDAJMG6>3.3.CO; 2-\#

21. Hae TS, Chan KC, Boo NY. Cardiovascular malformations in Malaysian neonates with Down syndrome. Singapore Medical Journal 1990; 31: 4746.

22. Venugopalan P, Agarwal AK. Spectrum of congenital heart defects associated with Down syndrome in high consanguineous Omani population. Indian Pediatrics 2003; 40(5):398-403.

PMid: 12768040

23. Otaigbe BE, Tabansi PN. Congenital heart disease in the Niger Delta region of Nigeria: a four year prospective echocardiographic analysis. Cardiovascular Journal of Africa 2014; 25: 265-8.

https://doi.org/10.5830/CVJA-2014-055

PMid: 25388927 PMCid: PMC4327180
24. Jou HJ, Kuo YS, Hsu JJ, Shyu MK, Hsieh TT et al. The evolving national birth prevalence of Down syndrome in Taiwan. A study on the impact of second trimester maternal serum screening. Prenatal Diagnosis 2005; 25(8):665-70. https://doi.org/10.1002/pd.1220 PMid: 16049991

25. Agathokleous M, Chaveeva P, Poon LC, Kosinski P, Nicolaides KH. Meta-analysis of second-trimester markers for trisomy 21. Ultrasound in Obstetrics and Gynecology 2013; 41(3):247-61. https://doi.org/10.1002/uog.12364 PMid: 23208748

26. Geelhoed EA, Bebbington A, Bower C, Deshpande A, Leonard H. Direct health care costs of children and adolescents with Down syndrome. Journal of Pediatrics 2011; 159(4): 541-5. https://doi.org/10.1016/j.jpeds.2011.06.00 7

PMid: 21784457 PMCid: PMC3858577

27. Kim JH, Hwang JM, Kim HJ, Yu YS. Characteristic ocular findings in Asian children with Down syndrome. Eye (Lond) $2002 ; 16: 710-4$.

https://doi.org/10.1038/sj.eye.6700208

PMid: 12439664

28. Kawar M, Dahabreh M, Hawamdeh A. Clinical spectrum and cytogenetic analysis of Down syndrome patients attending a referral clinic in Jordan. Eastern Mediterranean Health Journal 2010; 16(16):1211-3.

29. Wallis HRE. The significance of Brushfield's spots in the diagnosis of mongolism in infancy. Archives of Disease in Childhood 1951; 26:495-500 https://doi.org/10.1038/sj.eye.6700208 PMid: 12439664 